\title{
JUdGeS AS SUPERHEROES: THE DANGER OF CONFUSING Constitutional Decisions with Cosmic BattLes
}

\author{
H. Jefferson Powell*
}

I. INTRODUCTION

II. MANNING $V$. CALDWELL AS AN ORDINARY LEGAL CONTROVERSY .922

III. ManNing V. CALDWELl AS A Battle Between (Constitutional) GOOD AND EVIL .930

IV. MaNNING V. CALDWELL AS A CaUtionary TaLe 939

V. CONCLuSION

VI. APPENDIX: The PRINCIPAL DisSENT's OBSERVATIONS ABOUT THE EN BANC MAJORITY

A. Assertions and Suggestions About the Majority's Faithfulness to

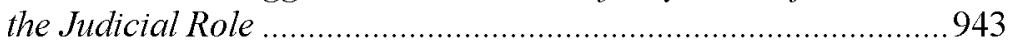

B. Assertions About the Effects of the Majority's Holdings ..............946

\section{INTRODUCTION}

We live in an era of superheroes warding off cosmic catastrophe, at least if movie box office hits are any measure. The official Marvel web page for the Avengers, for example, describes that large and somewhat amorphous group as "Earth's Mightiest Heroes" who "stand as the planet's first line of defense against the most powerful threats in the universe." For those who prefer logical consistency and coherent story lines, the Avengers movies may not be the best viewing choice, but logic and coherence are luxuries one cannot afford in the middle of a battle against universe-sized Evil. To insist on a calm and dispassionate examination of what makes sense misses the point.

* Professor of Law, Duke University. I greatly appreciate Sarah Powell's extensive and invaluable comments

1. Avengers, MARVEL, https://www.marvel.com/teams-and-groups/avengers [https://pe rma.cc/A2J7-7PV5] 
Judges are not superheroes, although the attention paid a few Supreme Court Justices suggests some confusion on that score. ${ }^{2}$ Judging is, or ought to be, characterized by logic and intellectual coherence. To do the job properly, judges must be capable of thinking clearly and calmly about the questions they address - even, or rather especially, when those questions involve matters about which people (including judges) feel passionately. In no area of law is this judicial obligation to reason dispassionately more important than in constitutional law, where the political, moral, and emotional stakes are often very high indeed. The Avengers, whatever their merits as the planet's cosmic defenders, make very poor role models for constitutional judges.

This Article suggests that the difference between constitutional adjudication and Avengers: Infinity $\mathrm{War}^{3}$ has become unclear to some judges. Superheroes in the Avengers model are engaged in titanic battles against Evil on behalf of Good; there is no question about which side to take, and cool detachment in decision-making would be a vice. In contrast, the "warring" sides in a constitutional controversy do not come prepackaged as Good or Evil, and a judge's task is to understand and evaluate conflicting arguments on issues that are often genuinely contestable even if, at the end of the evaluative process, the individual judge is convinced that one side is correct. Because intellectual and ideological predilections inevitably shape a judge's judgments about which arguments are more persuasive, constitutional decisions take place within institutional arrangements - centrally, the existence of appellate review by multi-member courts and the legitimacy of overruling precedent-that limit the influence of those predilections. The lines of disagreement over constitutional issues are not lines of defense against threats to existence or even to the Republic but are the consequence of differing perspectives among judges and others-all of whom may be, and generally are, acting in good faith. In an appellate case on which judges differ, those in the majority have not "won" a battle nor have the dissenters been defeated, and neither side are superheroes; they have simply disagreed on one or more points of law even if, in legal or human terms, the decision is crucially important and its consequences (if wrong) deeply regrettable. ${ }^{4}$

2. Any serious footnote substantiating this assertion risks losing up front the fans of any Justice that I suggest has become too much of a celebrity, so I will choose an example that even I think is more charming than alarming: the opera Scalia/Ginsburg. See Scalia/Ginsburg, DERRICK WANG, http://www.derrickwang.com/scalia-ginsburg [https://perma.cc/6TWE-DG3 E].

3. See Avengers: Infinity War, MARVEL, https://www.marvel.com/movies/avengersinfinity-war [https://perma.cc/HB86-FJ7B].

4. It is no part of my argument that judges - or anyone else - must wear kid gloves when arguing about the answers to constitutional questions. Nor do I deny there can be judicial opinions so intellectually indefensible that the presumption they are offered in good faith must 
To show that some judges have confused their role with that of the Avengers and to evaluate the unfortunate results of doing so, this Article considers the Fourth Circuit's 2019 decision in Manning v. Caldwell. ${ }^{5}$ Manning was a would-be class action challenging a set of Virginia statutes under which a person may be adjudicated a "habitual drunkard" and then subject to prosecution for offenses that apply only to someone with that status. ${ }^{6}$ The federal district court dismissed the complaint for failure to state a claim, and a panel of the Fourth Circuit affirmed. ${ }^{7}$ The appeals court then reheard the appeal sitting en banc and invalidated the habitual drunkard law, holding that it was both unconstitutionally vague and a violation of the Eighth Amendment. ${ }^{8}$ The en banc decision prompted an extraordinary exchange between Judge J. Harvie Wilkinson, who wrote the "principal dissent," and Judge Barbara Milano Keenan, co-author of the majority opinion, who filed a concurrence taking issue with the tone of Judge Wilkinson's principal dissent. ${ }^{10}$ In turn, Judge Wilkinson wrote a rejoinder joined by none of the other en banc dissenters. ${ }^{11}$

This Article first argues that Judge Wilkinson's two dissents reflect his assumption of the role of constitutional Avenger-a role that led him to misunderstand and mischaracterize the majority's opinion, to raise groundless doubts about the good faith of his majority colleagues, and to make these mistakes without perceiving that he was doing so. Second, it argues that the role Judge Wilkinson assumed is no idiosyncratic construct but is instead a

be abandoned. But we lose our ability to recognize intellectual dishonesty when it becomes the norm to treat constitutional disagreement as proof that opposing arguments cannot be the product of principled and intelligent (however misguided) thought. I am grateful to Joseph Blocher for pressing me on this point, which deserves greater development beyond the scope of this Article.

5. 930 F.3d 264 (4th Cir. 2019).

6. Id. at 264-65.

7. Hendrick v. Caldwell, 232 F.3d 868 (W.D. Va. 2017); Manning v. Caldwell, 900 F.3d 139 (4th Cir. 2018), vacated, 741 Fed. App'x 937 (4th Cir. 2018).

8. Manning, 930 F.3d at 270.

9. This term was used by the en banc majority opinion, the concurrence, and Judge Wilkinson himself. See, e.g., id. at 285; id. at 286 (Keenan, Cir. J., concurring); id. at 305 (Wilkinson, Cir. J., dissenting specially). All but one of the dissenters, Judge Albert Diaz, joined Judge Wilkinson's principal dissent. Id. at 286 (Wilkinson, Cir. J., dissenting). Judge Diaz filed a dissent speaking for himself alone, stating he agreed "with the substance of Judge Wilkinson's dissent" but "wr[ote] separately" because, unlike Judge Wilkinson, he thought the majority was right to decide the vagueness claim even if wrong "on its merits." Id. at 306 (Diaz, Cir. J., dissenting).

10. The other co-author of the en banc majority opinion was Judge Diana Gribbon Motz, who was on the original panel and concurred there solely on the ground that circuit precedent controlled the outcome and could not be disturbed except by the court en banc. See id. at 156 (Motz, Cir. J., concurring). Judge Motz and Judge Stephanie D. Thacker joined Judge Keenan's concurrence. $I d$. at 286 (Keenan, Cir. J., concurring).

11. Id. at 305 (Wilkinson, Cir. J., dissenting specially). 
serious and widely shared misunderstanding of the legal process in constitutional cases.

Part II discusses the constitutional issues before the Manning court and attempts to do so as fair-mindedly as possible, concluding that, as to both the vagueness and the Eighth Amendment issues, there are professionally respectable arguments on either side. In short, Manning involved genuinely contestable constitutional questions. It follows that the Manning judges' differing conclusions likely stem from differing political, ideological, or jurisprudential assumptions, but this in no way implies bad faith on the part of anyone. It is precisely when respectable legal arguments can be made on both sides of an issue that one should expect to find judicial disagreement tracking the extralegal commitments of the judges; those commitments shape their good faith judgments about which arguments are stronger.

Part III argues that, in Manning, Judge Wilkinson succumbed to the temptation to act as a constitutional Avenger. His dissents treated Manning as a battle in an apocalyptic struggle between constitutional Good and Evil and portrayed himself as the heroic defender of the Right and True. The majority's rejection of his views was therefore no mere legal error but a victory for the forces of constitutional Evil so portentous that Judge Wilkinson lost sight of the human import of his words. His principal dissent misunderstood and mischaracterized the majority's opinion and raised groundless doubts about the good faith of his majority colleagues, while his "special" dissent showed that, despite Judge Keenan's protests, he made those mistakes without perceiving he was doing. Because these are serious assertions to make about opinions written by a distinguished federal judge, much of Part III is devoted to substantiating them. ${ }^{12}$

Part IV explains why Judge Wilkinson's dissents are better seen not as a regrettable lapse by an individual judge but as an indication of a much broader phenomenon. The temptation to treat constitutional judges as warriors in an almost cosmic conflict is not new, but until recently, it has been primarily associated with the Supreme Court. We have grown accustomed to reading opinions by Justices who excoriate their colleagues for egregious lapses in reasoning and willful failure to abide by the limits of the judicial role. ${ }^{13}$ It is

12. For all of the statements in Judge Wilkinson's dissents that support my analysis, see infra Part VI. There are far too many to list in the main body of this Article.

13. See, e.g., Obergefell v. Hodges, 576 U.S. 644, $687-88$ (2015) (Roberts, C.J., dissenting) ("The majority's decision is an act of will, not legal judgment. The right it announces has no basis in the Constitution or this Court's precedent. The majority expressly disclaims judicial 'caution' and omits even a pretense of humility, openly relying on its desire to remake society according to its own 'new insight' into the 'nature of injustice.' . . . It can be tempting for judges to confuse our own preferences with the requirements of the law.... The majority 
unsurprising that presidents, senators, commentators, and the public have taken the Court's members at their word and have come to treat nominations to, and constitutional decisions by, the Court as events in an essentially ideological war.

One might respond that there is an inescapably political aspect to constitutional law and that, in a time of ideological polarization, the Supreme Court-with its unique prominence and role in the system-could hardly escape being viewed politically. Furthermore, the temptation for a Justice to don the mask of apocalyptic champion in these circumstances must be nearly overwhelming. The significance of Manning is that Judge Wilkinson's dissents suggest this temptation has become a serious one at the court of appeals level as well. Those courts almost always have the final word in how the federal system deals with individual persons in specific cases. If their judges see the law and themselves in fundamentally distorted ways, the

today neglects that restrained conception of the judicial role. It seizes for itself a question the Constitution leaves to the people[.]").

I quote this passage from the current Chief Justice's dissent from the Court's decision invalidating state laws that restrict marriage to opposite-sex couples not because it is exceptionally virulent or because he is especially prone to such language. My reason is quite the opposite: Chief Justice Roberts is usually a courteous and restrained debater by the standards of today's Court, and it would not be difficult to find opinions by other Justices with more sustained or personally insulting criticisms of their colleagues' work. If he, too, is liable to portray himself at times as a constitutional superhero battling the forces of Evil - colleagues with whom he has a disagreement over a question of law-this is prima facie evidence that the constitutionalAvenger temptation is rampant on the Court. And the passage I quote does not seem to me a fair criticism of the majority opinion in Obergefell. Substantive due process remains a highly controversial mode of constitutional analysis, but a Justice as noted for his genuine restraint as Justice John Marshall Harlan II accepted it as having an adequate "basis in the Constitution." See, e.g., Poe v. Ullman, 367 U.S. 497, 540, 542 (1961) (Harlan, J., dissenting) ("The [Constitution's] text ... is the only commission for our power" of judicial review and "due process is a discrete concept which subsists as an independent guaranty of liberty and procedural fairness, more general and inclusive than the specific prohibitions.").

I invite any reader inclined to accept the statement that holding unconstitutional a ban on same-sex marriage "has no basis in . . this Court's precedent" to consider Lawrence v. Texas, 539 U.S. 558, 558 (2003) (invalidating a state statute that criminalized same-sex sodomy), and United States $v$. Windsor, 570 U.S. 744, 745 (2013) (invalidating a federal statute that defined marriage for federal-law purposes as limited to opposite-sex couples). I do not imply either that the Court's decision was correct (that is a question for another day) or that the Chief Justice should have refrained from stating with great vigor his disagreement with the majority's reasoning. But labeling the majority opinion "an act of will" and a prideful and open attempt "to remake society according to its own" "preferences" and to "seize for itself a question the Constitution leaves to the people" either directly accuses the majority of willful misuse of its power or implies that the majority Justices do not understand what they are doing. See Obergefell, 576 U.S. at $687-88$. A reader concerned with understanding the points of constitutional disagreement in Obergefell, or what reasons persuaded the Chief Justice that the majority's legal reasoning was flawed, is not aided by Chief Justice Roberts's personal attack. 
negative consequences-for the law and for human beings-are incalculable. $^{14}$

\section{MANNING V. CALDWELL AS AN ORDINARY LEGAL CONTROVERSY}

The constitutional issues addressed in Manning $v$. Caldwell arose out of the peculiar features of the Virginia habitual drunkard law. The basic provision in the statutory scheme ${ }^{15}$ provides that when, after a hearing, "it appears to the satisfaction of the circuit court ... that any person, residing within such county or city ... has shown himself to be a habitual drunkard,

14. I shall pass over several interesting or puzzling features of the various opinions at each stage of the case. The en banc majority expressly stated that it was holding the habitualdrunkard scheme "unconstitutionally vague even as applied to these Plaintiffs," Manning, 930 F.3d at 278, while repeatedly describing its Eighth Amendment holding in terms of the case's procedural posture, see id. at 270 ("Plaintiffs have stated a claim that it violates the Eighth Amendment ...."); see also id. at 284. Although the majority opinion stated that the district court decision was "reversed and remanded," $i d$. at 286 , it is unclear what arguments the state could have advanced if the Virginia attorney general had not decided to acquiesce in the decision. See Letter from Mark R. Herring, Att'y Gen., Commonwealth of Va. Off. of the Att'y Gen., to Colette Wallace McEachin, Interim Commonwealth's Att'y, City of Richmond (Sept. 13, 2019) (on file with author).

Although the plaintiffs argued vagueness to the district court, they expressly declined to "press this claim" in their original appellate briefing. $I d$. at 271 . When the issue arose in the en banc oral argument, the court ordered supplemental briefing and, in the end, accepted the vagueness argument. $I d$. at $271-78$. The court's members were sharply divided on the propriety of reaching the argument. Compare $i d$. at 272 ("IT]here are compelling reasons ... to justify excusing Plaintiffs' initial abandonment of their vagueness claim...."), with id. at 301 (Wilkinson, Cir. J., dissenting) ("By reviving the vagueness claim now, we are inviting litigants to take this court for a ride. We should not, for want of a better word, be such chumps."), and $i d$. at 306 (Diaz, Cir. J., dissenting) ("I think it well within this court's discretion to consider Plaintiff's vagueness challenge...."). This Article ignores what is otherwise an interesting debate over an important practical question in appellate litigation.

Long before Manning, the Fourth Circuit rejected vagueness and Eighth Amendment challenges to a habitual-drunkard scheme in Fisher v. Coleman, 639 F.2d 191 (4th Cir. 1981) (per curiam). See Manning, 930 F.3d at 160 n.4 (Motz, Cir. J., concurring) (recognizing Fisher as controlling circuit precedent). Fisher was, to be sure, a summary affirmance of what the court termed the "thorough, well-reasoned opinion" of the district court. $639 \mathrm{~F} .2 \mathrm{~d}$ at 191 (affirming "for reasons sufficiently stated by that court"). But Fisher was a precedential decision announced through a published opinion, even if it referred the reader to the published district court order for its reasoning. See id. Therefore, at the very least, it is odd that the Manning district court treated Fisher as persuasive rather than binding authority, see Hendrick v. Caldwell, 232 F. Supp. 3d 868, 892 (W.D. Va. 2017) ("This court sees no reason to depart from the holding in Fisher... ."), while the panel opinion and the principal dissent, which agreed with Fisher's outcome, cited the decision without invoking stare decisis. See Manning, 930 F.3d at 289 (Wilkinson, Cir. J., dissenting).

15. The statutory provisions that make up the habitual-drunkard law are scattered, rather than grouped together, sections within the Virginia Code, but the en banc majority seems correct in describing them as "a series of interrelated statutes that operate as a single scheme." Manning, 930 F.3d at 268 (majority opinion). 
the court may enter an order of interdiction prohibiting the sale of alcoholic beverages to such person until further ordered." 16 The term "habitual drunkard" is nowhere defined nor are any standards given to guide the trial court's determination. ${ }^{17}$

The effect of an interdiction order is not limited to making it effectively impossible for an individual to find a legal source of alcohol. ${ }^{18}$ The order also significantly changes the individual's potential criminal law liabilities, making it a crime to purchase, possess, or consume alcoholic beverages, or to attempt to do so, punishable by up to one year in jail and a $\$ 2,500$ fine. ${ }^{19}$ Additionally, interdicted persons are subject to a separate offense of being "drunk in public," which carries the same potential penalties, despite the public intoxication statute applicable to non-interdicted persons carrying a maximum $\$ 250$ fine with no jail time. ${ }^{20}$

16. VA. CODE ANN. \$ 4.1-333(A) (West, Westlaw through 2021 Reg. Sess.). Section 4.1333 also authorizes a circuit court to issue an interdiction order upon proof that an individual has been convicted of driving while intoxicated. See $i d$. The Manning plaintiffs did not challenge this part of the provision. See $930 \mathrm{~F} .3 \mathrm{~d}$ at 268

Neither $\$ 4.1-333$ nor any other provision expressly provides a procedural mechanism for challenging a habitual-drunkard finding once made, although subsection (B) does authorize "[t]he court entering [the] order of interdiction [to] alter, amend or cancel such order as it deems proper." $\$ 4.1-333(B)$. In 2006, a Virginia prosecutor observed that, in his jurisdiction, an interdiction order "probably will last the offender's lifetime" because circuit court judges are "unlikely to remove the restriction." Virginia Beach Targets Repeat Drunken Drivers, THE VIRGINIAN-PILOT (May 14, 2006, 12:00 AM), https:/www.pilotonline.com/news/crime/article _cfe1c9b2-fce4-50cd-8bfb-6b90f13c5a0f.html [https://perma.cc/879E-N3EM].

In theory, it appears possible to appeal a habitual-drunkard determination, although that may be impractical for a homeless person - at least until charged with a crime dependent on habitual-drunkard status and given a court-appointed attorney. See Christie Thompson, When Just Being Near Alcohol Lands You in Jail, ThE MARSHALl ProJeCt (Sept. 7, 2018), https://www themarshallproject.org/2018/09/07/when-just-being-near-alcohol-lands-you-injail [https://perma.cc/8J7J-DBKE] (quoting a public defender who was challenging his client's status in a criminal appeal); see also Alex Koma, Arlington's 'Habitual Drunkards:' Prosecutors Enforce a Controversial Law Impacting the Homeless, ARLNOW (Jan. 16, 2019, 1:45 PM), https://www.arlnow.com/2019/01/16/arlingtons-habitual-drunkards-prosecutors-em brace-a-controversial-tactic-impacting-the-homeless/ [https://perma.cc/3JKN-WMTA] (quoting a public defender saying that, in her experience, judges dismiss a challenge to status as an impermissible collateral challenge to a civil judgment).

17. The term "habitual drunkard" contrasts with the term "intoxicated" used in other provisions, which is rather carefully described in the overall definitions section of the umbrella Alcoholic Beverage Control Act: "Intoxicated' means a condition in which a person has consumed enough alcoholic beverages to observably affect his manner, disposition, speech, muscular movement, general appearance, or behavior." $\$ 4.1-100$.

18. It is a misdemeanor to knowingly sell alcohol to an interdicted person. See $\$ 4,1$ 304(A). It is also a misdemeanor to purchase alcohol for someone known to be interdicted. See $\S 4.1-306(\mathrm{~A})$.

19. See $\$ 4.1-322 ; \S 18.2-11$.

20. See Manning, 930 F.3d at 269. 
Although the government must observe the Constitution's criminalprocedure requirements to impose these criminal penalties, the civil proceedings during which interdiction orders are issued provide minimal protection-particularly for unrepresented, homeless persons. ${ }^{21}$ The plaintiffs in Manning alleged, and it seems generally acknowledged as true, that habitual drunkard hearings often take place in the absence of the individual being considered and that free legal representation is not provided. ${ }^{22}$ In practice, the first time a homeless person under an interdiction order may learn of his or her status is upon arrest for violating one of the criminal law limitations on persons deemed habitual drunkards. ${ }^{23}$ The question before the Fourth Circuit was whether this statutory scheme was invalid, either because the term "habitual drunkard" was unconstitutionally vague or because the statutory scheme, at least as applied to homeless alcoholics, in effect criminalized their status. ${ }^{24}$

Considering vagueness, the principle that a statute may violate due process if it is "void for vagueness" has two distinct rationales: the law should define its limitations on individual liberty "with sufficient definiteness that ordinary people can understand what conduct is prohibited[,]" and it should do so "in a manner that does not encourage arbitrary and discriminatory enforcement." 25 The Supreme Court has further explained:

[T] he more important aspect of the vagueness doctrine "is not actual notice, but the other principal element of the doctrine-the requirement that a legislature establish minimal guidelines to govern law enforcement." Where the legislature fails to provide such minimal guidelines, a criminal statute may permit "a standardless sweep [that] allows policemen, prosecutors, and juries to pursue their personal predilections." 26

21. See Thompson, supra note 16.

22. See Manning, 930 F.3d at 268-69 (" $[A]$ lthough [state law] requires that any individual potentially subject to interdiction be permitted a 'hearing upon due notice,' the record shows that such hearings often are conducted without the defendant being present.").

23. See Thompson, supra note 16.

24. See Manning, 930 F.3d at 264-65.

25. Beckles v. United States, 137 S. Ct. 886, 892 (2017) (quoting Kolender v. Lawson, 461 U.S. $352,357(1983))$.

26. Kolender, 461 U.S. at 357-58 (quoting Smith v. Goguen, 415 U.S. 566, 574-75 (1974)). 
As this excerpt indicates, the vagueness doctrine is directed primarily at criminal statutes, but the Supreme Court has applied it in non-criminal contexts as well. ${ }^{27}$

"Habitual drunkard" is undefined by the statute, ${ }^{28}$ and the Virginia Supreme Court has not construed it. ${ }^{29}$ The Fourth Circuit's en banc majority concluded the term fails "to put [anyone] on notice about what conduct" leads to being adjudicated a habitual drunkard and leaves up "to the subjective view of judges and law enforcement officials" the "determination whether a certain person qualifies ... . Police officers, prosecutors, and even state circuit court judges likely will have differing perceptions regarding what frequency of drunkenness exceeds the necessary threshold . . ."30 Thus, in the majority's view, the statutory scheme taken as a whole "invite[s] arbitrary enforcement" and is invalid. ${ }^{31}$

27. See, e.g., Vill. of Hoffman Ests. v. Flipside, Hoffman Ests., Inc., 455 U.S. 489, 499 (1982) (applying the vagueness doctrine to an "ordinance [that] nominally impose[d] only civil penalties" but had a "prohibitory and stigmatizing effect"). The extra-criminal reach of the doctrine is not a relic from an earlier constitutional era; the Court recently struck down a civil provision of the Immigration and Nationality Act on vagueness grounds in Sessions v. Dimaya, 138 S. Ct. 1204, 1223 (2018). Sessions relied on earlier decisions, holding that "the most exacting vagueness standard should apply in removal cases" because of removal's severe consequences and thus does not stand for any general proposition about the scope of the vagueness doctrine's application to civil provisions. See id. at 1213. What it does demonstrate is that the doctrine is not categorically limited to criminal-law prohibitions.

28. The district court in Manning held that the plaintiffs lacked standing to challenge the habitual-drunkard law on vagueness grounds because it thought the plaintiffs were plainly within its scope. See Hendrick v. Caldwell, 232 F. Supp. 3d 868, 892 (W.D. Va. 2017). The en banc majority correctly rejected this argument, which Supreme Court and Fourth Circuit precedent foreclose, Manning, 930 F.3d at $278 \mathrm{n} .12$ (discussing the controlling cases), and the principal dissent properly did not rely on it.

29. A lone intermediate level state decision unhelpfully commented that a habitual drunkard is someone who is "in the continual habit of being intoxicated from alcohol," which is circular or nearly so. See Jackson v. Commonwealth, 604 S.E.2d 122, 125 (Va. Ct. App. 2004) (quoting Fisher v. Coleman, 486 F. Supp. 311, 315 (W.D. Va. 1979)). In doubting that Jackson adds anything material, I follow Judge Diaz, who wrote that "Virginia's courts haven't provided much guidance beyond that contained in the statutory text." Manning, 930 F.3d at 307 (Diaz, Cir. J., dissenting).

30. Manning, 930 F.3d at 274, 276 (majority opinion).

31. The majority conceded that, after being interdicted, "a person may be on notice about the conduct prohibited" because of his or her status but reasoned that it does not follow that the person was also on notice he or she could be interdicted. Id. at 274. The majority also asserted that the term's vagueness "support[ed] Plaintiffs' assertion that the law was designed to target persons, including the homeless, that state officials deem undesirable." Id. at 276. That observation could be relevant to an equal protection argument that the law is invalid because it rests on an illegitimate legislative purpose. See, e.g., United States v. Windsor, 570 U.S. 744, 770 (2013) ("The Constitution's guarantee of equality 'must at the very least mean that a bare congressional desire to harm a politically unpopular group cannot' justify disparate treatment of that group."). However, as the principal dissent correctly pointed out, the majority accepted the 
In contrast, the principal dissent reasoned that the "sole purpose" of the civil habitual drunkard determination is to put "high risk persons on notice of precisely what sort of acts will subject them to criminal sanctions ... ."32 For this reason, "[i]t ought to be obvious" that such a notice provision cannot "transgress th[e] constitutional limit" on vague criminal laws. ${ }^{33}$ And even if the vagueness doctrine applied, the dissent insisted that "the term is simply not vague under any conceivable standard[.] . . 'Habitual drunkard,' by its own language, requires both a pattern of behavior and a certain form of conduct, both of which are familiar to the law."34

The vagueness doctrine is not self-applying. On the one hand, putting aside the fact that the civil interdiction hearing may not provide adequate notice in practice, at least for homeless persons, ${ }^{35}$ the principal dissent plausibly argued that the doctrine simply does not apply to a statutory scheme providing a civil procedure that notifies an individual in advance of any criminal law consequences. ${ }^{36}$ On the other hand, the Supreme Court recently reaffirmed the importance of the doctrine's role in "guard[ing] against arbitrary or discriminatory law enforcement by insisting that a statute provide standards to govern the actions of police officers, prosecutors, juries, and

original panel's reasons for rejecting the complaint's equal protection claim. See Manning, 930 F.3d at 298 (Wilkinson, Cir. J., dissenting) (citing Manning, 930 F.3d at $270 \mathrm{n.5}$ (majority opinion)).

32. Manning, 930 F.3d at 301 (Wilkinson, Cir. J., dissenting)

33. The dissent asserts that "[t]he criminal nature of the doctrine is so prevalent that there was recently some debate about whether there could even be a proper standard for 'civil vagueness." Id. at 303 . The authority for that statement is a citation to the oral argument in Sessions. Id. (citing Transcript of Oral Argument at 39-41, Sessions, 138 S. Ct. 1204). The opinions filed in Sessions, however, do not support the dissent's suggestion. See Sessions, 138 S. Ct. at 1212 (plurality opinion) (observing that the vagueness doctrine often permits "greater tolerance of enactments with civil rather than criminal penalties"); $i d$. at 1229 (Gorsuch, J., concurring in part and concurring in judgment) ("[T]he happenstance that a law is found in the civil or criminal part of the statute books cannot be dispositive."); id. at 1250 (Thomas, J., dissenting) (acknowledging "[t]his Court's precedents" on vagueness, including challenges to non-criminal statutes). I do not understand the dissent's comment in Manning that "[o]ne need not have a view on th[e] question" of "whether there could even be a proper standard for "civil vagueness." Manning, 930 F.3d at 303 (Wilkinson, Cir. J., dissenting). Sessions-the controlling Supreme Court precedent on the issue-requires an appellate court judge to act on the affirmative answer to the question regardless of personal opinion. See $138 \mathrm{~S}$. Ct. at 1204 .

34. Manning, 930 F.3d at 301-02 (Wilkinson, Cir. J., dissenting).

35. Although there seems to be real cause for concern on this point, the plaintiffs did not squarely press this procedural due process issue before the en banc court. Id. at 268-69 (majority opinion).

36. Id. at 291-93 (Wilkinson, Cir. J., dissenting). 
judges. ${ }^{.37}$ It is not self-evident that the habitual-drunkard scheme is free from this problem.

The idea of vagueness, furthermore, invites differing judgments about where a given statutory phrase falls on a spectrum ranging from unmistakable clarity to unbounded vagueness. As Judge Albert Diaz wrote in a Manning dissent speaking for himself alone: "The distinction between occasional and 'habitual' drunkards is a question of degree, and it's true that the line may sometimes blur." 38 In his view, the statutory language fell on the acceptable end of the spectrum because the words clearly point to "the same basic conduct... [:] repeatedly consuming alcohol to excess." ${ }^{.39}$ By the same reasoning, however, someone more impressed by the imprecision of repetition and excess than Judge Diaz would be justified in concluding that the phrase falls too close to the unacceptably vague end of the spectrum. What matters here is that the majority's answer is not indefensible or outrageous.

The Eighth Amendment issue in Manning revolved around the scope of an old, well-known but rather unusual Supreme Court decision, Robinson v. California. ${ }^{40}$ Robinson struck down a state law that made it a crime to "be addicted to the use of narcotics," language that the state courts had construed as criminalizing the status of being addicted "whether or not [the individual] has ever used or possessed any narcotics within the State, and whether or not he has been guilty of any antisocial behavior there." 41 The Court invoked the Cruel and Unusual Punishment Clause as the textual basis for its conclusion, and as such, Robinson's core holding is settled law: mere status unrelated to a specific action cannot be the basis for criminal punishment. ${ }^{42}$ In Manning,

37. Sessions, $138 \mathrm{~S}$. Ct. at 1212 (plurality opinion); see also id. at 1228 (Gorsuch, J., concurring in part and concurring in judgment) ("Vague laws also threaten to transfer legislative power to police and prosecutors, leaving to them the job of shaping a vague statute's contours through their enforcement decisions."); Grayned v. City of Rockford, 408 U.S. 104, 108-09 (1972) ("A vague law impermissibly delegates basic policy matters to policemen, judges, and juries for resolution on an $a d h o c$ and subjective basis ....").

38. Manning, 930 F.3d at 307 (Diaz, Cir. J., dissenting).

39. Id.

40. See id. at 279 (majority opinion).

41. Robinson v. California, 370 U.S. 660,660 n.1, 666 (1962).

42. The Eighth Amendment label fits Robinson's substantive holding uneasily, and Justice White suggested at the time that Robinson was really a substantive due process decision in disguise. Compare $i d$. at 666-67 ("[A] law which made a criminal offense of such a disease would doubtless be universally thought to be an infliction of cruel and unusual punishment.... Even one day in prison would be a cruel and unusual punishment for the "crime' of having a common cold."), with id. at 689 (White, J., dissenting) (noting "the present Court's allergy to substantive due process" and suggesting that the majority "was hard put to find a way to ascribe to the Framers of the Constitution the result reached today rather than to its own notions of ordered liberty"). Justice Harlan, who only the year before had argued for the legitimacy of substantive due process, clearly understood Robinson in those terms. $I d$. at 679 
the question was whether this principle properly applied to Virginia's habitual-drunkard scheme as applied to the plaintiffs and other homeless alcoholics. ${ }^{43}$

As a literal matter, the Virginia law obviously does not present a Robinson problem: interdicted persons are subject to criminal punishment only when they take one of the actions that state law forbids interdicted persons to take. The Manning plaintiffs' argument was that, as applied to them and the class of homeless alcoholics they sought to represent, the habitual-drunkard scheme effectively criminalized their status; they drink compulsively and therefore cannot avoid violating the prohibitions on possession and consumption, and as a practical matter, they cannot conceal their drinking because they are homeless. ${ }^{44}$ The nominally civil determination that interdicted persons are habitual drunkards inevitably leads to criminal liability. While the en banc majority found this argument persuasive, the dissenters did not. ${ }^{45}$

The authors of Manning's majority and principal dissent sparred at some length over the significance of the Supreme Court's most relevant postRobinson decision-Powell v. Texas, which rejected a Robinson challenge to a public intoxication statute but produced no opinion of the Court. ${ }^{46}$ The Manning majority correctly pointed out that Justice White cast the pivotal fifth vote against the challenger for evidentiary reasons while expressly agreeing with the four dissenting Justices that, "[u]nless Robinson is to be abandoned[,] ... the chronic alcoholic with an irresistible urge to consume alcohol should not be punishable for drinking or for being drunk." ${ }^{47}$ The principal dissent's response was that Justice White's comments about Robinson's applicability are not controlling because he actually "voted to uphold the conviction on the ground that Powell's behavior involved a volitional act [,]" and Powell has been generally understood as limiting Robinson to statutes that criminalize mere status. ${ }^{48}$

This debate over how to read Powell-which, in both opinions, spurred further disagreement over the authority of dicta and the rule in Marks v. United

(Harlan, J., concurring) (stating addiction law was "an arbitrary imposition which exceeds the power that a State may exercise in enacting its criminal law"); cf. Poe v. Ullman, 367 U.S. 497 , 543 (1961) (Harlan, J., dissenting) (acknowledging due process guarantees "freedom from all substantial arbitrary impositions and purposeless restraints").

43. Manning, 930 F.3d at 281 (majority opinion).

44. Id. at 269

45. Id. at 270; id. at 286-87 (Wilkinson, Cir. J., dissenting)

46. See Powell v. Texas, 392 U.S. 514 (1968) (plurality opinion); id. at 541-42 (Black, $\mathrm{J}$. , concurring); $i d$. at 553-54 (White, $\mathrm{J}$, concurring in the result).

47. 930 F.3d at 280 (quoting Powell, 392 U.S. at 548-49 (White, J., concurring in the result)).

48. Id. at 289 (Wilkinson, Cir. J., dissenting) (emphasis added) (citing Powell, 392 U.S at 553-54 (White, J., concurring in the result)). 
States $^{49}$ — seems undeniably inconclusive. Perhaps for that reason, in his separate dissent, Judge Diaz suggested that the question of "whether Robinson can and should be extended ... is one to be answered in the first instance by the Supreme Court." ${ }^{50}$ But in its most persuasive formulation, the en banc majority's Eighth Amendment reasoning does not claim to extend Robinson at all. ${ }^{51}$ The habitual-drunkard scheme is an integrated set of statutory provisions in which the civil determination changing an individual's legal status is enforced by criminal sanctions; in turn, the criminal prohibitions are offenses only for those who have the legal status imposed by that civil determination. "Virginia's two-pronged statutory scheme may be less direct than the statute at issue in Robinson, but it yields the same result: it effectively criminalizes an illness." 52 This is an argument not for extending Robinson but

49. The infamous rule in Marks is that, in a Supreme Court decision with no majority opinion, lower courts should follow "that position taken by those Members who concurred in the judgments on the narrowest ground." 430 U.S. 188, 193 (1977) (quoting Gregg v. Georgia, 428 U.S. 153,169 n.15 (1976)). Justice White's opinion clearly qualifies, but that does not resolve which parts of the opinion are "the position" that is controlling. I agree with the principal dissent that it is unpersuasive to construe Powell as an expansion of Robinson, but it is equally problematic to claim that the majority's reading of Powell "runs headlong into a large chorus of circuit court opinions" to the contrary. Manning, 930 F.3d at 289 (Wilkinson, Cir. J., dissenting).

The "large chorus" in fact disappears under even quick examination:

Far from it. Of the four cases the principal dissent cites in support of this assertion, two erroneously treated the plurality opinion in Powell as the holding of the Court and two are cursory and unpersuasive decisions from the same circuit. In fact, the only other circuit to squarely confront the issue has arrived at the same conclusion we reach here.

Id. at $282 \mathrm{n} .17$ (majority opinion) (citations omitted).

50. Id. at 307 (Diaz, Cir. J., dissenting). Like the other dissenters, Judge Diaz also appeared to think the narrow reading of Robinson was the better one. Id. ("I am satisfied that Robinson is better understood as distinguishing status from conduct . ..."). I am not convinced that Judge Diaz is correct. Except in a case factually indistinguishable from a Supreme Court precedent, any lower court that applies the precedent could be described as "extending" the Court's decision, but that is not ordinarily viewed as illegitimate. Endless case law under 28 U.S.C. $\$ 2254(d)(1)$, which limits federal habeas relief for state prisoners, illustrates how difficult it is to decide just what a Supreme Court precedent "clearly establishes." See, e.g., Shoop v. Hill, 139 S. Ct. 504, 506 (2019) (interpreting $\$ 2254$ (d)(1)'s reference to state court determinations "contrary to, or involv[ing] an unreasonable application of, clearly established Federal law, as determined by the Supreme Court of the United States").

51. It is fair to note that the majority's opinion at one point described its Eighth Amendment holding in somewhat different terms. See Manning, 930 F.3d at 284 ("The challenged statutory scheme threatens [plaintiffs] with arrest and incarceration for conduct that is not proscribed as a consequence of a prior criminal conviction, does not rest on even a single volitional element, and is lawful for all others of legal drinking age."). The majority later insisted: "our holding neither creates nor supports the notion of a nonvolitional defense against generally applicable crimes." $I d$. at 285 .

52. Id. at 283; see also id. "If the statute challenged in Robinson had instead allowed California to 'interdict' prescription drug addicts and then arrest interdicted addicts for filling 
for recognizing that Robinson stated a constitutional principle and that courts generally accord such principles generous, rather than parsimonious, interpretations. Treating a statute that "effectively" criminalizes status as within the original scope of Robinson is not unreasonable; indeed, it is clear from his opinion in Powell that Justice White understood Robinson as doing so. ${ }^{53}$ The principal dissent's response was that even constitutional principles have their limits. ${ }^{54}$ In arguing on the basis of what Virginia law "effectively criminalizes," the majority "ignore[d] the fact that the Virginia scheme actually bases criminal liability on specific acts. ${ }^{.55}$ It seems either treatment of Robinson is defensible. ${ }^{56}$

As with vagueness, what matters for present purposes is not who has the better Eighth Amendment argument. The important points are that the question of whether Robinson applies in Manning is a debatable one, that smart lawyers reasoning in good faith can come to either conclusion, and that there is no sound reason to treat either position as beyond the scope of legitimate judicial decision.

\section{Manning $V$. Caldwell as a Battle Between (Constitutional) GOOD AND EVIL}

The Fourth Circuit's en banc judgment in Manning rests on applications of the vagueness doctrine and the old Robinson decision that are simply not dictated by precedent. The majority's assertions that its holdings are actually compelled by precedent, like the principal dissent's claims that controlling precedent forecloses those holdings, exemplify the common judicial tendency to dignify a defensible reading of authority with the accolade of being the only defensible reading. This is hyperbolic to be sure but unlikely to mislead any experienced reader. It would have been quite surprising if the court had been unanimous, but in expressing this predictable disagreement, three of the Manning opinions discussed issues of judicial process beyond the expression

\footnotetext{
those prescriptions, the statute effectively would also have criminalized 'being addicted to narcotics' even if it nominally punished only filling prescriptions. Such a statute would surely be just as unconstitutional as the statute in Robinson, and for precisely the same reasons.").

53. See Powell, 392 U.S. at 548-49 (White, J., concurring in the result).

54. See Manning, 930 F.3d at 286 (Wilkinson, Cir. J., dissenting).

55. Id. at 292 .

56. Reading the en banc majority's holding as an application, rather than expansion, of Robinson also reasonably answers the principal dissent's concern about the scope of the holding. We are very far indeed from the problem the dissent foresees of perpetrators of otherwise criminal actions claiming a Robinson defense because those actions were the involuntary product of a psychopathology. See id. at 292-93. The Eighth Amendment holding in Manning addresses, and logically can be limited to, a statutory regime in which otherwise lawful conduct is criminalized solely because of a legal status imposed by the state. Id. at 284 (majority opinion).
} 
of differing professional judgments on points of constitutional law. ${ }^{57}$ In summarizing their arguments, Part II carefully avoided naming in the text the authors of the en banc majority opinion, Judges Motz and Keenan, or the author of the principal dissent, Judge Wilkinson. Now, it is time to bring back to conscious awareness the fact that important appellate opinions in our judicial system are not ordinarily anonymous institutional papers. They are statements signed by individually named judges. Even when judges speak for colleagues or the court, they speak in a personal voice and implicitly display their personal understanding of the court's role, the judicial office, and the significance of the case being decided. When judges ascribe motives and objectives to colleagues, they make personal observations that all readers will note and are entitled to take seriously.

Judge Wilkinson's principal dissent went beyond a discussion of disputed legal issues in two related but distinct respects. First, he repeatedly indicated that, in his view, the majority was not only mistaken but willfully mistakendeliberately acting beyond the outer limits of legitimate judicial decisionmaking. ${ }^{58}$ Second, he repeatedly emphasized that the implications of the majority's decision are far-reaching, radical, and destructive. ${ }^{59}$

About this first claim, consider the following statements and word choices: ${ }^{60}$

- "Instead of simply applying the law as it is, my colleagues strive for something new[.]"61

- 'It is in the end a matter of respecting both the Supreme Court's authority to overturn its own decisions, and the limits of a circuit court's authority to find circuitous routes around higher controlling precedent." $" 62$

- "I do not understand why the majority would go to such lengths to thwart attempts to ameliorate these conditions." 63

- "[T]he majority feels itself empowered to hinder that progress" on dealing with "often alcohol-related offenses such as domestic violence and sexual assault[.]"64

- "All the richness and diversity of our fifty state democracies is now swept aside for a single policy preference. The majority thinks that

57. Id. at 265 .

58. Id. at 287 (Wilkinson, Cir. J., dissenting).

59. See id.

60. For a more complete list, see supra Part V.

61. Manning, 930 F.3d at 286 (Wilkinson, Cir. J., dissenting).

62. Id. at 291 .

63. Id. at 294.

64. Id. at 296. 
because it invokes the word 'constitution' it is empowered through that incantation to displace other branches and other levels of government with its own transcendent views of how best to regulate a species of conduct with which it has no expertise and over which it has no authority. Such a malleable constitution; such adjudicative power: Caesar Augustus would be envious."

- "The result is that constitutional doctrine will become ever more sprawling, ever more confusing, and judges will seize upon that same confusion to further work their personal will."

- "The whole point of the majority's faux textualism is not to respect the lawmaker's intent but to undermine it, and in doing so to aggrandize the power of the judiciary vis-à-vis the legislative branch by picking critically and ceaselessly at enacted words. ${ }^{.67}$

As to the second claim - that Judge Wilkinson described the implications of the majority's decision as catastrophic - here is a sampling:

- "'The majority] has discarded any pretense of a workable limiting principle, expanded the Eighth Amendment beyond any discernible limits, and overturned sixty years of controlling Supreme Court precedent .... Unfortunately, Supreme Court precedent will not be the only victim of this decision. ... The consequences will fall on the most vulnerable, especially the victims of domestic abuse and sexual assault. How ironic that the majority would stand on the cusp of the centennial of women's suffrage and deal a setback not only to the physical safety of women, but to their basic right to peace of mind .... Its decision will also interject the federal courts into areas traditionally and wisely reserved for the states, subverting both the democratic process and dual sovereignty ...."

- "This case is an assault upon the constitutional, democratic, and common law foundations of American civil and criminal law, and most importantly, to the judge's place within it." 69

- "[The majority's reasoning] threatens to change the character of criminal law as we have known it."70

70. Id. at 292 . 
- "It is hard to imagine a decision so infused with ruinous consequences or so insensitive to a judge's inability to rework society from the bench." 71

- "This decision is an affront to our legal traditions. It leaves states less able to enact prophylactic civil laws and sanctions in order to forestall more serious crimes. It usurps the American Constitution in order to cement the states as subordinate entities in our federal structure."72

Judge Wilkinson is a long-standing, distinguished member of the federal judiciary; a former chief judge of the Fourth Circuit (often mentioned in the past as a potential Supreme Court nominee); and author of, among other works, a book about the mischievous effects of "cosmic constitutional theories" on an appropriately constrained understanding of the role of courts in our constitutional system. ${ }^{73}$ A dissent by such a judge to a major constitutional decision is influential not just for its reasoning but also because of the author's stature. The manner in which that dissent discusses the judge's colleagues and their decision unavoidably invites the reader to make judgments about those colleagues' good faith and legitimate decision-making. In his principal dissent in Manning, Judge Wilkinson put his prestige and personal authority behind what clearly seems to accuse Judge Motz, Judge Keenan, and the other majority judges of deliberately misusing their office to reach conclusions that are legally indefensible and institutionally disastrous.

Judge Keenan's short concurrence responding to Judge Wilkinson says as much. She began by noting "the alarmist tone of the principal dissent" and suggesting it was far-fetched to describe the decision as an "assault" on the Constitution, American democracy, and the common law foundations of legal tradition. ${ }^{74}$ "What were the principal dissenters reading when they reached these conclusions? Surely not the majority's opinion, addressing arguments that a Virginia statutory scheme is vague and targets homeless alcoholics based on their compulsion to consume alcohol."75 Judge Keenan then identified the broad issue of judicial process that Judge Wilkinson's dissent raised:

71. Id. at 304.

72. Id. at 304-05.

73. See J. Harvie WILkinson, Cosmic Constitutional Theory: Why Americans Are Losing Their Inalienable Right to Self-Governance 4 (Geoffrey R. Stone ed., 2012) [hereinafter COSMIC CONSTITUTIONAL THEORY]. For more on Judge Wilkinson and the Supreme Court, see, for example, Jess Bravin, High-Court Contenders Exchange Barbs, WALL ST. J. (June 27 2005, 12:01 AM), https://www.wsj.com/articles/SB111983817739570131 [https://perma.cc/4WLA-NEFQ].

74. Manning, 930 F.3d at 286 (Keenan, Cir. J., concurring).

75. Id. at 286 . 
I make these observations because I worry about the message that we convey to the public when we attempt to bolster a legal analysis by making assertions suggesting malfeasance by judges who disagree with our position. And what message do we send to trial judges and lawyers who know that such assertions are false? Will they view these broadsides as evidence of institutional disharmony? Such attacks are not part of a "vigorous exchange of views," but instead detract from any substantive analysis.

As judges, we all take our duty to faithfully interpret the law as a solemn obligation. That we reach different conclusions in applying the law to a given case should be of no moment. What is truly important is that we have a legal system that allows for good-faith disagreements and provides for further review by a higher court. ${ }^{76}$

Judge Keenan made three important assertions in these two paragraphs. First, she asserted the principal dissent's language departed from the Fourth Circuit's "cherished tradition of civility." This is not simply a question of etiquette. It is undoubtedly bad manners to insinuate your colleagues have misused their office, but it is, for both the accuser and the accused, something deeper-a misleading distraction from the hard task of discerning and applying the rules of law that govern the appeal before them. The time and emotional energy a dissenter diverts to making ad hominem attacks and apocalyptic predictions about a decision's consequences do not strengthen the dissenter's own arguments or enable majority colleagues to address weaknesses in their own. In fact, such language interferes with any real exchange of views about the legal issues before the court.

Second, Judge Keenan asserted that the angry and often sarcastic tone of an opinion like the principal dissent is out of place because it reflects a deep misunderstanding of the sources of disagreement in law. Legal doctrines that require courts to make judgments of degree unsurprisingly lead to conflicting judgments at times, and the question about how broadly to treat precedent, such as Robinson, is answered not by logical deduction but by considerations of fit analogy and purpose. As Chief Justice John Marshall wrote long ago, "[t]he judgment is so much influenced by the wishes, the affections, and the general theories of [the decision maker] that a contrariety of opinion on [a] great constitutional question ought to excite no surprise." 78 Chief Justice Marshall did not mean that this renders constitutional answers indeterminate or simple matters of preference. But his wise observation reminds us that "a

76. $I d$.

77. Id

78. JOHN MARSHALl, The LIFE OF GEORGE WASHINGTON 591 (Chelsea House 1983). 
contrariety of opinion" in a case like Manning is no indication that any judge is acting ineptly or in bad faith.

Finally, Judge Keenan's concurrence drew attention to the fact that an appellate court opinion is, unavoidably, a commentary on the state of the court, its members, and the law it administers-a commentary that may, in turn, affect how others view these matters. ${ }^{79} \mathrm{We}$ live in a time of deep political polarization where many people are ready to view judges as partisan political actors and objectionable constitutional answers as illegitimate political choices. An opinion like Judge Wilkinson's confirms these suspicions, not just by indicting the majority judges for acting on personal preference but equally by inadvertently portraying himself as unwilling or unable to recognize even the possibility of "good-faith disagreement" in Manning.

Judge Wilkinson did not simply ignore Judge Keenan's criticisms. There is no indication that he altered the principal dissent, but he filed an additional opinion "dissenting specially" and only speaking for himself. ${ }^{80}$ This special dissent briefly restated his conviction that "the doctrinal march of the majority opinion is indeed 'an assault upon the . . foundations of American . . law,"” while denying that the principal dissent "attributed to [the majority] "malfeasance" and affirming his admiration and affection for "such capable and dedicated jurists." $" 81$ Accepting his sincerity, it is unclear how Judge Wilkinson could expect the reader to take seriously his assertion that the Fourth Circuit "is truly fortunate to have the services" of the judges in the majority. ${ }^{82}$ Judges who write or join an opinion "usurping the American Constitution" sound more like candidates for impeachment than "dedicated jurists" deserving public respect. ${ }^{83}$

Most interesting about the special dissent, however, is Judge Wilkinson's response to Judge Keenan's claim that the language of the principal dissent was out of place:

[T] he very purpose of a dissenting opinion is to illuminate difference, not to evidence disrespect. To my mind, mutual respect and collegiality are enhanced, not compromised, by a vigorous exchange of views over basic and fundamental principles of law. ... That we discharge our oath of office with conviction and at times with passion is something I believe the public and the profession will respect. ... [W]e have in this case a deep and honest difference of

79. Manning, 930 F.3d at 286 (Keenan, Cir. J., concurring).

80. Id. at 305 (Wilkinson, Cir. J., dissenting specially).

81. Id. at $305-06$.

82. Id. at 306 .

83. The reference to the majority's usurpation of the Constitution is from id. at 305 (Wilkinson, Cir. J., dissenting). 
opinion the importance of which can neither be brushed off nor wished away. It is after all a dissent to which my colleagues take exception. The very nature of the effort is one of contrast. And so it is here. ${ }^{84}$

In other words, Judge Wilkinson's strong language in the principal dissent displays the candor and passion with which he discharged his judicial duty, a sign of his adherence to judicial ideals rather than a departure from them.

According to Judge Wilkinson, it is Judge Keenan's invocation of civility that was misplaced:

I am reminded of the words of Justice Douglas that "[s]peech is often provocative and challenging" and that "a function of free speech under our system of government is to invite dispute." In positing that speech "may indeed best serve its high purpose when it ... stirs people to anger," Justice Douglas missed a point rightly grasped by my concurring colleagues - namely that civil discourse is often the best antidote to a coarsening culture. But one need not subscribe wholly to the Justice's full-throated cry in order to recognize that civility, for all its value, may also be used as a censoring mechanism to drain and dilute dissenting voices. Flaws are not always best laid bare by pallid speech. Animation defines the First Amendment I was taught to revere. ${ }^{85}$

In stating his dissenting views with "passion" and "animation," Judge Wilkinson believed that the principal dissent served the high constitutional purpose of resisting censoring mechanisms, including the self-censorship that overconcern about civility might involve. Such mechanisms are inconsistent with the First Amendment commitment to ensuring that speakers and, above all, dissenting speakers may express their views as they deem most effective and without interference from the majority they are criticizing. In his special dissent, Judge Wilkinson did not recant his harsh descriptions of the en banc majority's reasoning and their purposes in Manning; in his terms, those descriptions expressed his views with appropriate animation.

Whatever Judge Wilkinson's intentions, readers of the principal dissent will likely conclude that the dissent is accusing the en banc majority of using shoddy, unconvincing arguments to reach policy results that the majority judges happen to favor. Rather than depicting a reasoned disagreement, such accusations portray a contest between the opinion's author, who is implied to

84. Id. at 305-06 (Wilkinson, Cir. J., dissenting specially).

85. Id. (quoting Terminiello v. Chicago, 337 U.S. 1, 4 (1949) (alteration in original)).

86. Id. 
be acting on principle, and his targets, who are acting in apparent bad faith. The principal dissent's expressions of alarm over the "ruinous consequences" of the decision seem to be almost equally objectionable. ${ }^{87} \mathrm{~A}$ dissenter who points out the potential negative consequences of a decision plays a valuable role, but depicting Manning as a critical defeat in a titanic struggle between Good and Evil considerably overstates its significance. Judicial opinions are intended to be reasoned discussions that persuade the reader by cogency of thought rather than by simply appealing to the reader's suspicions or fears. A dissenting opinion can do so without lapsing into "pallid speech" and is even more effective when its rhetoric supports the argument instead of classifying the majority's decision as anything other than a differing, good-faith view of the issues.

The principal dissent in Manning is, of course, not the first constitutional opinion to indulge in overstatement and personal innuendo. The Justices of the Supreme Court have, for some time now, set a bad example in that regard. Most interesting about the debate between Judges Keenan and Wilkinson is what the latter's special dissent reveals about his understanding of the judicial process, at least in the context of debatable constitutional law issues. Judge Wilkinson's special dissent suggests that, when appellate judges disagree over such issues, their disagreement lies on the same continuum of expression as overtly partisan and political clashes. If their disagreement goes deep enough, the judges' opinions are appropriately an "exchange of views" somewhat resembling the "dialogue" of opposing political candidates; anger, sarcasm, hyperbole, and insinuations about the covert purposes of one's opponent become acceptable means of vigorously asserting a particular position. The public and profession will recognize this, as they do in other First Amendment contexts, while other judges must either endure a colleague's tone or (presumably) respond in kind. Where writers deem it necessary to make their points with the passion and conviction they wish to project, civility must simply give way.

Judge Wilkinson's invocation of the First Amendment is bizarre. The amendment is indeed construed to protect speech that is overheated, impolite, and unfair; Supreme Court decisions recognize the danger that governmental demands for civility may be "used as a censoring mechanism to drain and dilute dissenting voices. ${ }^{9} 88$ But it seems almost a jest to suggest this constitutional principle has any relevance to the dissenting voice of a

87. Id. at 304 (Wilkinson, Cir. J., dissenting).

88. Id. at 306 (Wilkinson, Cir. J., dissenting specially); see, e.g., N.Y. Times v. Sullivan, 376 U.S. 254, 270 (1964) (discussing the "profound national commitment to the principle that debate on public issues should be uninhibited, robust, and wide-open, and that it may well include vehement, caustic, and sometimes unpleasantly sharp attacks on government and public officials"). 
distinguished, life-tenured judge on the federal appellate bench. It is "a function of [constitutional] free speech ... to invite dispute," and Justice Douglas's words quoted by Judge Wilkinson come from a decision that protected provocative and unpopular political speech from governmental interference ${ }^{89}$ But because Judge Wilkinson is the government, or part of it, and is quite beyond anyone's ability to censor, Justice Douglas's words do not seem apposite.

More importantly, in suggesting that Judge Wilkinson's defense of his tone in Manning implicitly accepts the existence of significant continuity between judicial opinions on constitutional law and political speech, it is important to recall that he is a prominent advocate of modesty in constitutional adjudication-a judge who believes that "the highest virtues of judging ... are a measure of self-denial and restraint" and that "law is something above and apart from the personal preferences of men and women on the bench. ${ }^{90}$ Surely such a legal thinker is at the furthest remove from views that collapse the distinction between law and politics. There can be no doubt that Judge Wilkinson is both an accomplished legal thinker and one committed to the propositions just quoted. But how can he both hold those commitments and associate his principal dissent in Manning with the intellectually vacuous, hate-mongering speech Justice Douglas had in view? The answer lies in Judge Wilkinson's perception of the current state of constitutional law.

A few years ago, Judge Wilkinson wrote a book in which he discussed his claim that federal constitutional law is in the midst of a long-standing struggle between judges who adhere to a traditionally constrained understanding of the judiciary's role and judges who have succumbed to the temptation of implementing through constitutional law what they believe to be good social policy. ${ }^{91}$ And the traditionalist judges are gradually losing: "By and large, self-restraint has waged a running battle with activist tendencies on the bench for more than a century, with the latter, albeit haltingly, more ascendant over time." 92

This running battle is, from Judge Wilkinson's perspective, one that traditionalists wage to defend an ideal of judging that is impersonal and dispassionate ${ }^{93}$ But the struggle itself is political and necessarily so because, in the end, there is no shared, adequate framework for debate between traditionalists and practitioners of "judicial adventurism" who subscribe to

89. Manning, 930 F.3d at 305-06 (Wilkinson, Cir. J., dissenting specially) (quoting Terminiello, 337 U.S. at 4).

90. COSMic CONSTITUTIONAL THeORY, supra note 73, at 116.

91. See id. at 114.

92. Id. at 110

93. Id. at 114 
differing constitutional theories dependent on their varying political preferences. ${ }^{94}$ In his book, Judge Wilkinson lamented that "no one can now plausibly make the claim that judging is impersonal [or] that constitutional rulings are dispassionate," $" 95$ and his opinions in Manning demonstrate that politicization is a two-way street. Precisely because constitutional law has become a Manichean struggle between constitutional Right and Wrong, the champion of constitutional Right cannot afford to fight with a blunt sword. The defender of Good must be able to critique the forces of constitutional Evil with much the same freedom from civility, constraint, or fair-mindedness practiced in straightforward political expression. In defense of an ostensibly apolitical view of judging, someone in Judge Wilkinson's shoes must use political weapons. He cannot afford to pull his punches. In a crisis, hesitating over whether to sound the alarm because it might be shrill could be a fatal mistake.

In this context, Judge Wilkinson's invocation of Justice Douglas makes perfect sense. In Terminiello v. City of Chicago, Justice Douglas was celebrating, in his own characteristically overheated fashion, the popular American image of the lonely, heroic individual taking a stand against vast, oppressive forces. ${ }^{96}$ That image is tailor-made for a judge convinced that constitutional disagreements are regularly battles between Good and Evil. In Manning, Judge Wilkinson took on the persona of Justice Douglas's hero: he transformed himself into a constitutional Avenger.

\section{Manning V. CALDWELl as a CaUtionary TaLE}

One response to the argument in Part III is that Judge Wilkinson's dissents in Manning are no more than a lapse in judgment by a careless individual. It would be comforting yet implausible to think so. Judge Wilkinson is no reckless "Wild Bill" - as Justice Douglas eventually made of himself ${ }^{97}$ - he is an erudite jurist with a demonstrated concern for proper execution of the judicial role. But Judge Keenan's temperately worded concurrence did not prompt Judge Wilkinson to reconsider either his doomsaying description of the Manning decision or the drumbeat of personal accusation, sarcasm, and anger running through his principal dissent. His special dissent offered a personal compliment to the majority judges that seems empty when embedded

94. See id. at 115. Judge Wilkinson does not believe that the "constitutional interventionism" he decries is limited to one end of the political spectrum: it is "startling in both frequency and degree, and widely practiced on all sides." Id. at 114 .

95. Id. at 114.

96. See Terminello v. City of Chicago, 337 U.S. 1,6 (1949).

97. See generally BRuCE MuRPHy, WiLd BILL: THE LEGEND AND LifE OF WILLIAM O. DOUGLAS (2003) (discussing Justice Douglas's life and accomplishments). 
in an uncompromising re-assertion that the principal dissent's pages of invective were justified.

The isolated, incident interpretation of the Manning dissents is further undermined by the fact that, for whatever reason, the judges who joined the principal dissent were content to allow that opinion alone-with its overstatement, harshness, and personal innuendo - to represent their views of the decision and of their majority colleagues. ${ }^{98}$ Apparently those members of the Fourth Circuit believe it is appropriate to accuse colleagues of abusing their office without offering so much as a fig leaf of personal good will. To borrow a question Judge Keenan asked in her concurrence, "what message" of "institutional disharmony" does their silence "send to trial judges and lawyers who know that such assertions are false?"99

This Article's answer is an unhappy one. The Supreme Court's decisions on constitutional questions often matter a great deal to human beings individually and to American society generally. At times, the Court's legal error may lead to deeply regrettable, or even morally reprehensible, consequences. But the Justices' role is not that of superheroes fostering the Good and warding off Evil; they are judges, commissioned to answer questions of law in good faith and to the best of their abilities. Because goodfaith disagreement over constitutional issues of the greatest consequence is inevitable, as Chief Justice John Marshall pointed out long ago, constitutional law depends on the ability of judges, lawyers, elected officials, and citizens to accept this inevitability and, almost always, the legitimacy of such disagreement even if one side of the dispute seems profoundly wrong. ${ }^{100}$ Civility toward those with other views - even at the expense of reining in rhetoric-is essential to the judicial task. ${ }^{101}$

Unfortunately, leading members of the Supreme Court-from all points on the political and jurisprudential spectrum-have confused themselves and the legal community about this for decades. The profession has grown accustomed to opinions written to express moral outrage, to portray conflicting views as intellectually indefensible, and to denounce decisions the writer thinks incorrect as egregious acts of self-will. Manning illustrates a portion of the price that is paid when other judges follow this lead. An

98. Perhaps Judge Wilkinson was unwilling to allow others to join his special dissent, but the judges who joined the principal dissent were under no obligation to do so or to leave that opinion as the sole expression of their views. Judge Diaz dissented, explaining his disagreements with the majority in an opinion entirely free of ad hominem attacks. Manning v. Caldwell, 930 F.3d 264, 306-07 (4th Cir. 2019) (Diaz, Cir. J., dissenting).

99. Id. at 286 (Keenan, Cir. J., concurring).

100. See MARSHALL, supra note 78, at 591.

101. "[I]n this world, with great power there must also come-great responsibility." Kimble v. Marvel Ent., 576 U.S. 446, 465 (2015) (quoting STAN LeE \& STEve DitKo, 15 AMAZING FANTASY: SPIDER-MAN 13 (1962)). 
individual reading only Judge Wilkinson's principal dissent would never assume there are serious arguments on each side of Manning's two constitutional issues, much less that a principled and intelligent judge could reach the conclusions that Judge Wilkinson rejects.

As Manning shows, judges who don the mask of heroic defenders of Good simultaneously impose on their colleagues the corresponding mask of unprincipled advocates of Evil. ${ }^{102}$ In doing so, judges lose sight of their colleagues' humanity and engagement in a common effort to discern and apply the law. Self-appointed constitutional Avengers are likely to exaggerate the extent to which congenial legal arguments are obviously correct and underestimate the extralegal commitments that may be affecting their judgment. They lose sight of their actual, more modest role as participants in the constitutional process, which is, in reality, characterized more by Judge Keenan's "good-faith disagreements" over points of law than by "affronts to our legal traditions" or deliberate usurpations of the Constitution. ${ }^{103}$ And a judge who takes on the role of superhero makes it that much more difficult for others - colleagues and observers alike - to see anything in constitutional law other than the expression of self-will.

\section{CONCLUSION}

What if Judge Wilkinson is right? Perhaps constitutional law is under attack from within, and the en banc opinion in Manning $v$. Caldwell is another indication of how far the enemies of legitimate constitutional adjudication have succeeded in replacing our traditional norms of decision with their insidious, politically motivated counterfeit. If so, perhaps it was Judge Wilkinson's duty to raise the alarm, and his only error was disavowing any

102. In using the language of masks, I am of course borrowing the concept of legal masks that the late Judge John T. Noonan Jr. presented in his classic book, Persons and Masks of the Law.

103. Judge Wilkinson's repeated characterizations of the Manning decision's catastrophic consequences illustrate one of the ways in which the role of judge-as-superhero distorts one's judgment. The Manning decision is without doubt of great human importance for individuals in Virginia - homeless alcoholics and public officials alike - who are affected by the invalidation of the habitual-drunkard law. But only one other state currently has a similar scheme, see UTAH CODE ANN. $\$ 32$ B-2-605 (2020), and Manning (itself subject to abrogation by a later Supreme Court decision) is controlling precedent only in the Fourth Circuit. Even Supreme Court decisions have limits; to assert that a single circuit's decision "threatens to change the character of criminal law as we have known it" shows a remarkable failure in perspective. See Manning, 930 F.3d at 292 (Wilkinson, Cir. J., dissenting). 
suggestion of malfeasance. If Thanos is indeed mounting his final assault on the planet, superheroes are needed. ${ }^{104}$

As indicated in Part I, that apocalyptic mindset has no place in constitutional adjudication. This is emphatically not because judges can or should lack strong moral and political commitments. Precisely because constitutional issues are often of great importance to some, and occasionally to all, one of the most important contributions judges can make is to turn down the emotional thermostat in their opinions. In an age of deep ideological passion, judges ought to model the virtues of dispassionate reason. If questions invite dogmatic, irreconcilable answers, judges must employ language evidencing their consideration of both sides of the argument. When the rest of us find it difficult to credit political opponents with good faith and intelligence, judicial opinions should remind us that "a contrariety of opinion on [a] great constitutional question ought to excite no surprise." ${ }^{105}$ But judges can fulfill these duties only if they keep in mind that they are not superheroes, and their decisions are not battles in a cosmic war.

\section{APPENDIX: The PRINCIPAl Dissent's ObSERVATIONS ABOUt THE EN BANC MAJORITY}

I do not intend to suggest that every passage quoted below is objectionable in isolation, and many need to be read in context in order to come to a final conclusion about their meaning. The thesis of this Article is based on what I believe to be the unmistakable message of the dissent's language taken as a whole.

104. Thanos is "a despot of intergalactic infamy" who is the chief villain in the Marvel superhero movies Avengers: Infinity War (2018) and Avengers: Endgame (2019). See Avengers: Infinity War, supra note 3. Cinematic parallels aside, this apocalyptic vision is presumably how adherents to one of the stricter forms of originalism view non-originalist Justices - if there are any non-originalist Justices left. See, e.g., We the People Podcast, Justice Neil Gorsuch, Live at America's Town Hall, INTERACTIVE CONST. (Sept. 19, 2019), https:/constitutioncenter.org/inte ractive-constitution/podcast/justice-neil-gorsuch-live-at-americas-town-hall [https://perma.cc/T S8E-82CA] (discussing Justices Ginsburg, Kagan, and Gorsuch all describing themselves as originalists).

The Manning principal dissent does not disagree with the majority opinion over the correct theory of constitutional interpretation, however. Indeed, Judge Wilkinson uses the same tools of case analysis, analogy, and the like as the majority employs. The contrast he draws is not between conflicting theories but between (his) honest and (their) disingenuous use of standard doctrinal modes of argument. See, e.g., Manning, 930 F.3d at 286-87 (Wilkinson, Cir. J., dissenting).

105. MARSHALL, supra note 78, at 591. 
A. Assertions and Suggestions About the Majority's Faithfulness to the Judicial Role

- "Instead of simply applying the law as it is, my colleagues strive for something new ...."'106

- "[The majority] has discarded any pretense of a workable limiting principle...."107

- "The majority professes to believe . . . "108

- "My colleagues ... tease their preferred reading from the dicta of a single justice."109

- "[The majority judges] are mistaking themselves for occupants of a higher bench." 10

- "It is in the end a matter of respecting both the Supreme Court's authority to overturn its own decisions, and the limits of a circuit court's authority to find circuitous routes around higher controlling precedent."

- "Perhaps aware that the status-act distinction is still operative, the majority strains to fit within the test . . ." "112

- "In its rush to condemn the Virginia statute, the majority makes no more than passing mention of 'the ill effects of alcoholism' ... averting its eyes from the painful reasons why states regulate alcohol in the first place."113

- "I do not understand why the majority would go to such lengths to thwart attempts to ameliorate these conditions." 114

- "[T]he majority, despite its protests to the contrary, would use "the Eighth Amendment [to] tie the hands of state officials."

- "The majority purports to hold that schemes such as Virginia's constitute cruel and unusual punishments."116

106. Manning, 930 F.3d at 286 (Wilkinson, Cir. J., dissenting).

107. Id. at 287.

108. Id.

109. Id. at 290

110. Id.

111. Id. at 291.

112. Id. at 292.

113. Id. at 293.

114. Id. at 294.

115. Id. (second alteration in original).

116. Id. at 295. 
- "As my colleagues apparently see it, consuming alcohol, even by those with a documented history of alcohol abuse, is just not the sort of conduct that warrants criminal sanctions." 117

- 'I would hope that settled law was enough to prevent the majority from second-guessing the Commonwealth's judgment. But I find it particularly distressing that at a time when we are beginning to make some modest progress on often alcohol-related offenses such as domestic violence and sexual assault that the majority feels itself empowered to hinder that progress." 118

- "The majority decision aspires to rework our constitutional system."119

- 'Under our federal system, the "states possess primary authority for defining and enforcing the criminal law.' That is no impediment to the majority, which rushes in where others fear to tread."120

- "In its lecture on psychology and sermon to the states, the majority does not even acknowledge the many features of state law . . .."121

- "[State law] approaches to nonvolitional conduct often rely upon democratic input, making them far more sensitive and balanced than the constitutional theory developed by the majority on the fly." 122

- "All the richness and diversity of our fifty state democracies is now swept aside for a single policy preference."123

- "The majority thinks that because it invokes the word 'constitution" it is empowered through that incantation to displace other branches and other levels of government with its own transcendent views of how best to regulate a species of conduct with which it has no expertise and over which it has no authority. Such a malleable constitution; such adjudicative power: Caesar Augustus would be envious." 124

- "[T]his bald circumvention of settled law . . ."125

117. Id. at 296

118. Id.

119. Id. at 297 .

120. Id. (quoting United States v. Lopez, 514 U.S. 549, 561 n.3 (1995)).

121. Id.

122. $I d$.

$123 . I d$. at 298 .

124. Id.

125. Id. at 299. 
- "It seems that the Eighth Amendment is coming into fashion as a means for striking down both civil and criminal laws that display no constitutional defect but merely fail to comport with the majority's sense of optimal public policy."126

- "The result is that constitutional doctrine will become ever more sprawling, ever more confusing, and judges will seize upon that same confusion to further work their personal will."127

- "The majority has provided no standard ... other than "whenever it suits us." "128

- "Put simply, this statute presents no problem that vagueness doctrine could possibly solve. The majority . . . is undeterred." 129

- "The whole point of the majority's faux textualism is not to respect the lawmaker's intent but to undermine it, and in doing so to aggrandize the power of the judiciary vis-à-vis the legislative branch by picking critically and ceaselessly at enacted words. Only an approach as ad hoc and pliable as the majority's could lead to [its] conclusion ...."130

- "The approach to vagueness adopted by the majority transparently incentivizes the semantic destruction of many kinds of statutes of whose purpose a court does not approve." 131

- "The majority casually applies its pick to a civil law, showing an utter indifference to the consequences of its novel venture."132

- "The majority tries to evade the implications of its civil vagueness theory ...." "133

- "The inconsistency of the majority's view is the inevitable result of stretching vagueness doctrine to meet its preferences . . ." "134

- "The majority's civil vagueness holding shares with its Eighth Amendment holding the same disregard for Supreme Court precedent, the same unwillingness to confront obvious implications, and the same failure to provide any workable limits .... What it has

126. $I d$.

127. Id

128. Id. at 300 .

129. Id at 301.

130. Id. at 302-03.

131. Id. at 303 .

132. Id.

133. Id at 304.

134. Id. 
created is a confusion which promotes judicial ascendency by inviting litigants to trek again to Delphi for yet another inscrutable judicial decree." 135

- "It is hard to imagine a decision so infused with ruinous consequences or so insensitive to a judge's inability to rework society from the bench. First, the desire to remove unspecified acts from the purview of criminal law ...."136

- "I only wish that my colleagues, in their rush to condemn Virginia for a policy they don't prefer, stopped to consider that perhaps this law has endured for the benefit of the many victims of alcohol-fueled violence. ..." ."137

- "All pretensions to restraint have been abandoned."

\section{B. Assertions About the Effects of the Majority's Holdings}

- "[The majority] has discarded any pretense of a workable limiting principle, expanded the Eighth Amendment beyond any discernible limits, and overturned sixty years of controlling Supreme Court precedent .... Unfortunately, Supreme Court precedent will not be the only victim of this decision. The majority's new theory of the Eighth Amendment will foreclose a state's ability to take reasonable steps to protect its citizens from serious and long recognized harms. The consequences will fall on the most vulnerable, especially the victims of domestic abuse and sexual assault. How ironic that the majority would stand on the cusp of the centennial of women's suffrage and deal a setback not only to the physical safety of women, but to their basic right to peace of mind .... Its decision will also interject the federal courts into areas traditionally and wisely reserved for the states, subverting both the democratic process and dual sovereignty ...."

- "The majority's notion of civil vagueness imperils a whole range of previously uncontroversial statutes ...."140 
- 'There is nothing 'narrow' about the majority's holding or its reasoning. This case is an assault upon the constitutional, democratic, and common law foundations of American civil and criminal law, and most importantly, to the judge's place within it."141

- "[The majority's Eighth Amendment reasoning] threatens to change the character of criminal law as we have known it."142

- "AAs a consequence of the majority's reasoning, f]rom this point on ... 'nonvolitional conduct' will enter the gallery of go-to phrases used to curtail the capacity of democratic governments to protect the people from a veritable slew of allegedly nonvolitional criminal acts. "143

- "[The majority's reasoning] prohibits legislative bodies from making the altogether practical assessments of risky behaviors that are entirely within the legislative prerogative."144

- "The majority upends our system of dual sovereignty. It puts judges in policymaking roles reserved largely for legislatures and states."145

- "[The majority's Eighth Amendment holding] will erode the careful structure of the Constitution." 146

- 'But after today's holding, many laws, both civil and criminal, will be vulnerable ...."147

- $\quad$ "Future litigants will rely on this case endlessly to excuse inexcusable carelessness, or worse, calculated litigation strategy that in hindsight proved unsuccessful." 148

- 'In sum, the majority would outlaw 'general definition[s]' and terms from many state enactments."

141. Id

142. Id. at 292.

143. Id. at 293. Judge Wilkinson's use of scare quotes is odd: the phrase belongs to him, rather than the majority, which used it only once and in response to his dissent. The majority does use similar expressions, such as "conduct that is an involuntary manifestation of their illness." See, e.g., id. at 284-285 (majority opinion).

144. Id. at 296 (Wilkinson, Cir. J., dissenting).

145. Id. at 297.

146. Id. at 298 .

147. Id. at 299 .

148. Id. at 301.

149. $I d$. at 302 (alteration in original). 
- "As if this novel view of civil vagueness were not enough, the majority takes it one step further by tearing up state law, striking yet another blow to the state's rightful place in our federal system."150

- "It is hard to imagine a decision so infused with ruinous consequences or so insensitive to a judge's inability to rework society from the bench." 151

- "The clear and principled status-act distinction is now replaced with a nebulous 'nonvolitional conduct' defense, a phrase that will surely metastasize and absolve individuals from personal responsibility for all forms and manners of criminal acts." 152

- "This decision is an affront to our legal traditions. It leaves states less able to enact prophylactic civil laws and sanctions in order to forestall more serious crimes. It usurps the American Constitution in order to cement the states as subordinate entities in our federal structure, a result profoundly at odds with the vibrant federalism that was intended to define not only our young but our maturing Republic."153

- "[The majority"s] novel theory of civil vagueness... calls into question countless expressions in numerous civil laws. The effects of this position will long be felt, as all manner of words and phrases will be impugned for their alleged imprecision." 154 